\title{
Genotoxicity Evaluation of Capsaicin-Containing (CP) Pharmacopuncture, in an In Vivo Micronucleus Test
}

\author{
Ji Hye Hwang ${ }^{1}$, Jaseung Kư ${ }^{2}$ Chul Jung ${ }^{3 *}$ \\ ${ }^{1}$ Department of Acupuncture \& Moxibustion Medicine, College of Korean Medicine, Gachon University, Seongnam, Republic of Korea \\ ${ }^{2}$ Bogwang Korean Medical Clinic, Seoul, Republic of Korea \\ ${ }^{3}$ Namsangcheon Korean Medicine Clinic, Seoul, Republic of Korea
}

Received September 25, 2020

Reviewed October 10, 2020

Accepted November 12, 2020

*Corresponding Author

Chul Jung

Namsangcheon Korean Medicine Clinic,

Seoul 06656, Republic of Korea

Tel: +82-2-583-0325

E-mail: jcnu2000@hanmail.net
Objectives: Capsaicin-containing (CP) pharmacopuncture was developed to treat neuropathic pain. This study was conducted to assess the toxicity of CP extract for pharmacopuncture, using a micronucleus test.

Methods: First, a dose range finding study was conducted. Then an in vivo micronucleus test was performed to determine the induction of micronuclei in mouse bone marrow cells after intramuscular administration of CP twice with a 24-hour interval to 8-week-old ICR mice. A high dose of $0.2 \mathrm{~mL} /$ animal was selected, and this was sequentially diluted by applying a geometric ratio of 2 to produce two lower dose levels $(0.1$ and $0.05 \mathrm{~mL} /$ animal). In addition, negative and positive control groups were set up, and an HPLC analysis was conducted to confirm the capsaicin content of CP.

Results: The incidence of micro-nucleated polychromatic erythrocytes in polychromatic erythrocytes in the CP-treated group was similar to that in the negative-control group, while that in the positive-control group was significantly greater. In addition, the ratio of polychromatic erythrocytes to total erythrocytes in the CP treatment group and the positive control group was not significantly different from the negative control group. In the HPLC analysis, capsaicin in the CP was identified through a comparison with the retention time of the capsaicin standard of $27 \mathrm{~min}$.

Conclusion: $\mathrm{CP}$ did not show any indication of any potential to induce micronuclei formation in bone marrow cells of ICR mice under the conditions of this study. Further toxicity studies are necessary to ensure the safety of the use of CP in clinical practice.

Keywords: safety, acupuncture, in vivo micronucleus test, capsaicin, toxicity, capsaicincontaining pharmacopuncture (CP)

\section{INTRODUCTION}

Capsaicin, the main active ingredient in capsicum fruits, has been reported to be effective in treating inflammatory disorders (such as psoriasis and rheumatoid arthritis) [1], neuropathic pain (such as diabetic neuropathy), postherpetic neuralgia and cluster headaches [2], urinary system diseases [3], obesity [4], cancer $[5,6]$, and skin diseases $[7,8]$.

Pharmacopuncture is an acupoint injection therapy used in traditional Chinese medicine (TCM) and Korean medicine (KM) that involves the injection of herbal medicine, and it is considered to be faster and more effective than oral administration $[8,9]$. Because of this characteristic, it is widely used for musculoskeletal diseases.

The capsaicin-containg (CP) extract for pharmacopunture is a medicine that contains mainly red pepper based on $\mathrm{V}$ pharmacopunture, and it was developed to control pain. $\mathrm{V}$ pharmacopunture mainly uses moschus, calculus bovis, and fel ursi, and its safety and efficacy have been proven through long-term clinical experience, toxicity evaluation, efficacy studies (such as anti-inflammatory and antioxidant effects), and clinical reports [10-12]. CP was developed to treat neuropathic pain such as 
nerve entrapment and neurosensory abnormalities, myofascial pain, and hypertrophy by utilizing the capsaicin component contained in red pepper.

There have been no systematic, scientific, clinical, or experimental studies on the efficacy of $\mathrm{CP}$, with the exception of 2 case reports of patients with hypoesthesia of lower limb [13] and acute low back and thigh pain [14]. Our earlier studies confirmed the safety of CP by a single-dose toxicity test [15] and a bacterial reverse mutation test [16]. Whilst the safety of $\mathrm{CP}$ has been confirmed by clinical experience, further scientific verification of its efficacy and safety is needed before it is widely used in KM clinics. In this study, we investigated the safety of $\mathrm{CP}$ using an in vivo micronucleus test in ICR mice.

\section{MATERIALS AND METHODS}

\section{Material}

Test substance, CP, consists of Capsicum annuum L. (Korean, $11 \mathrm{mg} / \mathrm{mL}$ ), moschus (Russian, $0.1 \mathrm{mg} / \mathrm{mL}$ ), fel ursi (Russian, $0.075 \mathrm{mg} / \mathrm{mL}$ ), calculus bovis (Colombian, $0.05 \mathrm{mg} / \mathrm{mL}$ ), Scutellaria baicalensis (Chinese, $10 \mathrm{mg} / \mathrm{mL}$ ), Phellodendron amurense (Chinese, $10 \mathrm{mg} / \mathrm{mL}$ ), Pulsatilla koreana (Chinese, $10 \mathrm{mg} / \mathrm{mL}$ ), Sophora tonkinensis (Chinese, $10 \mathrm{mg} / \mathrm{mL}$ ), and Aucklandia lappa (Chinese, $5 \mathrm{mg} / \mathrm{mL}$ ). Capsicum annuum L. was purchased from Aruifarm (Yeonggwang, Korea), and the other raw materials were purchased from Jayeondameun (Yangju, Korea). CP was manufactured at an extramural facility, Namsangcheon Herbal Medicine Dispensary (Yongin, Korea), meeting Korean Good Manufacturing Practice standards. Two extraction methods were used depending on the type of herbal medicine. Animal medicines such as moschus, fel ursi, and calculus bovis were mixed with water and alcohol, and the remaining herbal medicines were distilled with water. First, moschus, fel ursi, and calculus bovis were extracted using water and alcohol $(\mathrm{v} / \mathrm{v}=1: 1)$ at $65^{\circ} \mathrm{C}$ for $24 \mathrm{~h}$, and then the alcohol was removed at $45^{\circ} \mathrm{C}$ using a vacuum pressure concentrator. Second, the other raw materials were distilled using a low-temperature vacuum extractor with purified water for injection, and then the distillate was collected. After mixing the extractions, the finished extract was diluted with purified water for injection and filtered sequentially with Whatman No.2 filter paper and 5 $\mu \mathrm{m}, 0.45 \mu \mathrm{m}$, and $0.2 \mu \mathrm{m}$ cellulose acetate filter. After adding salt to the filtered $\mathrm{CP}$ solution, $\mathrm{pH}$ titration was completed. CP was provided as the finished product $(56.225 \mathrm{mg} / \mathrm{mL}$ in a sealed vial).

Mitomycin C (MMC, Lot No. SLBR6518V, Sigma-Aldrich, St Louis, MO, USA) was used as a positive control and normal saline was used as a negative control. For injection of the positive control substance, $4 \mathrm{~mL}$ of water (Lot No.: 18003, JW Pharmaceutical Co., Ltd., Korea) was added to $2 \mathrm{mg}$ of MMC to dissolve the MMC, and then $6 \mathrm{~mL}$ of normal saline was added to prepare a final concentration of $0.2 \mathrm{mg} / \mathrm{mL}$.

\section{Experimental animals}

ICR mice were selected for this study because they are, as rodents, the most widely used animal species in safety tests including micronucleus tests, and much basic data has been accumulated for comparison. Also, they are the animal species recommended in the guidelines [17-19]. The ICR mice were purchased from Orient Bio Inc. (Seongnam, Korea). When the animals first arrived, a visual inspection was performed and their weight was recorded with electronic scales (BP410S; Sartorius, Gottingen, Germany). The general condition and changes in the animals were checked once a day during 1 week of acclimatization, and all animals were judged to be normal. The ICR mice were housed under controlled environmental conditions with an ambient temperature of $20.0-22.1^{\circ} \mathrm{C}$, relative humidity of $50.8-56.9 \%, 12 \mathrm{~h} / 12 \mathrm{~h}$ light/dark cycle, ventilation frequency 10-15 times/hour, illuminance 150-300 Lux, and free access to food (Teklad Certified Irradiated Global 18\% Protein Rodent Diet 2918C, Envigo, Huntingdon, UK) and water (purified water irradiated with ultraviolet rays after filtering tap water in Cheongju (Korea) with a filter water flowing sterilizer). Groupings were done after the acclimatization period.

For a dose range-finding study prior to the micronucleus tests, 8-week-old, male $(\mathrm{n}=12,32.1-35.6 \mathrm{~g})$ and female mice $(\mathrm{n}=12,25.3-28.4 \mathrm{~g})$ were used. For the micronucleus tests, 8-week-old, male mice ( $\mathrm{n}=25,27.5-31.6 \mathrm{~g})$ were used. In the dose setting test, no dead animals of either sex were observed; thus, only male mice were used for the remaining tests. The weight range of the mice was 33.0-36.9 g.

All animal care and use followed the Korean National Institute of Health and the Korean Academy of Medical Sciences guidelines, and this study was conducted at Biotoxtech (Cheongwon, Korea) under the regulations of Good Laboratory Practice (GLP) under the approval of the Institutional Animal Ethics Committee of Biotoxtech (No. 180774). 


\section{In vivo micronucleus test in mice}

\section{1) Dose range-finding study}

In order to determine the high-dose level of the main study, a dose range-finding study was conducted. In KM clinical practice, $\mathrm{CP}$ is administered intramuscularly. Intramuscular administration was selected because the path for clinical application of the test substance, $\mathrm{CP}$, is muscle. In the guidelines [18-20], the maximum dose for intramuscular injection of mice is recommended as $0.1 \mathrm{~mL}$ per site ( 2 sites per day). In this experiment, the high dose was selected as $0.2 \mathrm{~mL} / \mathrm{animal}$, and the extract was sequentially diluted by applying a geometric ratio of 2 to produce lower dose levels ( 0.1 and $0.05 \mathrm{~mL} /$ animal). The extract was administered intramuscularly in divided doses so as not to exceed $0.1 \mathrm{~mL}$ per site. Three males and females were used for each dose, and a disposable syringe $(0.3 \mathrm{~mL}, 31 \mathrm{G})$ was used for the test substance group. The 0.05 and $0.1 \mathrm{~mL} / \mathrm{animal}$ for the low and medium doses, respectively, and $0.2 \mathrm{~mL} /$ animal for the high dose and negative control substances were administered in the muscle of the thigh twice at 24-hour intervals. General symptoms of each dose were observed immediately after the first administration, 2 hours after the first administration, before the second administration, immediately after the second administration, 2 hours after the second administration, and 1 day after the second administration. Body weight was measured on the 1st day after the 2 nd administration.

\section{2) Main study}

There was no mortality or abnormal clinical signs at any dose level of the test substance in either male or female mice. Because there was no mortality in either males and females in the dose-range finding study, only males, which are known to be susceptible to micronucleus induction, were used in the main study. Five animals were used in each group, and the group size was set to five (Table 1).
A disposable syringe $(0.3 \mathrm{~mL}, 31 \mathrm{G})$ was used for the test substance group; and 0.05 and $0.1 \mathrm{~mL} /$ animal for low (G1) and medium (G2) doses, respectively, and $0.2 \mathrm{~mL} /$ animal for high doses (G4) and negative control substances (G1) were administered in the muscle of the thigh twice at 24-hour intervals. Administration was carried out intramuscularly in divided doses so as not to exceed $0.1 \mathrm{ml}$ per site. The positive control MMC (G5) used an intraperitoneal administration method, which is a general administration method. The dosage amount was 10 $\mathrm{mL} / \mathrm{kg}$ based on body weight when the group was separated, and it was administered once 24 hours before sample preparation using a disposable needle $(26 \mathrm{G})$ and a syringe $(1 \mathrm{~mL})$.

General symptoms of each dose were observed immediately after the first administration, 2 hours after the first administration, before the second administration, immediately after the second administration, 2 hours after the second administration, and 1 day after the second administration. Body weight was measured immediately before bone marrow collection.

Next, for sample preparation and observation, the cervical spine of the animals was dislocated 24 hours after the second administration of the test substance. After the femur was excised to remove muscle mass, bone marrow cells were collected by perfusing $200 \mu \mathrm{L}$ of fetal bovine serum (FBS, Lot No.: 1957600, Gibco, U.S.A.) by cutting the ends of the femur with scissors. Bone marrow cell suspension was centrifuged for 5 minutes (1,000 rpm, $4^{\circ} \mathrm{C}$, Micro17TR, Hanil Science Industrial Co., Ltd., Korea). After removal of the supernatant, the precipitated bone marrow cells were suspended, and a small amount was dropped on a slide glass and smeared. Two bone marrow smears were prepared per individual. The code number was written on the slide glass, and the sample was dried sufficiently and fixed with methanol. Then it was stained for 30 minutes with $3 \%$ Giemsa staining solution [prepared with $0.01 \mathrm{~mol} /$ L Sörenson phosphate buffer solution ( $\mathrm{pH}$ 6.8)]. The stained slides were washed with $0.01 \mathrm{~mol} / \mathrm{L}$ Sörenson phosphate buffer

Table 1. Micronucleus test in ICR mice

\begin{tabular}{clccccc}
\hline & Group & Dose $(\mathrm{mL} /$ animal $)$ & $\begin{array}{c}\text { Dose amount } \\
(\mathrm{mL} / \text { animal })\end{array}$ & $\begin{array}{c}\text { Frequency of } \\
\text { administration }\end{array}$ & $\begin{array}{c}\text { Route of } \\
\text { administration }\end{array}$ & $\begin{array}{c}\text { Number of animals } \\
(\mathrm{male})\end{array}$ \\
\hline G1 & Negative control & 0 & 0.2 & 2 & I.M. & 5 \\
G2 & Low-dose & 0.05 & 0.05 & 2 & I.M. & 5 \\
G3 & Mid-dose & 0.1 & 0.1 & 2 & I.M. & I.M. \\
G4 & High-dose & 0.2 & 0.2 & 2 & I.P. & 5 \\
G5 & Positive control & $2 \mathrm{mg} / \mathrm{kg}$ & $10 \mathrm{~mL} / \mathrm{kg}$ & & 5 \\
\hline
\end{tabular}

I.M., intramuscular; I.P., intraperitoneal. 
( $\mathrm{pH}$ 6.8) and $0.004 \%$ citric acid aqueous solution, dried, and then sealed with an encapsulant (Entellan new, Merck, Germany). The coded bone marrow smear was observed under a microscope (600 times magnification, BX51, Olympus, Japan). Two thousand polychromatic erythrocytes (PCE) per specimen were observed, 4,000 PCE per specimen were observed, and the frequency of appearance of micronucleated polychromatic erythrocyte (MNPCE) for each PCE was calculated. As an index of inhibition of proliferation of bone marrow cells, a total of 250 red blood cells per specimen was observed, and the ratio of PCE to 500 total red blood cells per specimen was calculated.

\section{3) Test establishment conditions and result judgment}

The test was established when the following two conditions were satisfied. First, in the negative control group, the frequency of micronucleus polychlorinated red blood cells should be within the control range of historical control data and $95 \%$ of historical control data. Second, the frequency of micronuclear polyinflammatory red blood cells in the positive control group was within the management range of historical control data, and it should increase statistically significant compared with the negative control group.

If the following three conditions were satisfied, it was determined as positive. The frequency of occurrence of MNPCE should increase statistically significantly at more than one dose compared with the negative control group, there should be dose dependence in accordance with the increase, and the frequency of occurrence of MNPCE should increase beyond the management range of historical control data of the negative control group.

\section{Statistical analysis}

Statistical analysis was performed using SAS (version 9.3, SAS Institute Inc., USA) for the frequency of appearance of MNPCE, frequency of appearance of PCE relative to total red blood cells, and changes in body weight. The Kruskal-Wallis test and Mann-Whitney test were performed for the frequency of MNPCE appearance, and the significant difference between the negative control group and the test substance, CP group, and between the negative control group and the positive control group were tested $(\mathrm{p}<0.05$ and $\mathrm{p}<0.01)$. Bartlett's test was performed on the frequency and weight of PCE for total red blood cells to test for equal variability between the negative control group and the test substance group $(\mathrm{p}<0.05)$. For the frequency of appearance of PCE for total red blood cells, the weight of the dose setting test (male) and the main test (male) were of equal variance, and the significance was confirmed by conducting a one-way analysis of variance (ANOVA; $\mathrm{p}<0.05$ ). The weight of the dose setting test (female) was rejected, and the KruskalWallis test was conducted to confirm the significance $(\mathrm{p}<0.05)$. For the comparison between the negative control group and the positive control group, the Folded-F test was performed to test for equal variance $(p<0.05)$. Equal variance was recognized, and a Student $\mathrm{t}$-test was performed to confirm significance $(\mathrm{p}<$ 0.05 and $\mathrm{p}<0.01)$.

\section{HPLC analysis}

To confirm the capsaicin content of CP with capsaicin (Cat no.: C107691, Aladdin, CA, USA) as an active ingredient, HPLC was conducted using CP, CP stock solution (CP100) corresponding to 100 times the concentration of $\mathrm{CP}$ used in clinical practice as the finished product $(56.225 \mathrm{mg} / \mathrm{mL}$ in a sealed vial), and capsaicin standard (STD). The HPLC apparatus was a Waters Delta600 (Waters, Milford, MA, USA) with a photodiode array (PDA) detector. An Inertsil ODS-3 analytical column ( $3 \mu, 250 \times 4.6 \mathrm{~mm}$; Metachem, GL Sciences, Japan) was employed. Chromatography was performed at room temperature with a wavelength of $229 \mathrm{~nm}$ (PDA), a flow rate of $0.5 \mathrm{~mL} / \mathrm{min}$, and isocratic of methanol:water (7:3). The capsaicin standard was diluted in methanol and used for analysis.

\section{RESULTS}

\section{HPLC analysis}

In HPLC analysis of CP, capsaicin in the CP was identified through a comparison with retention times (RTs) of authentic standards (Fig. 1). Using the capsaicin standard (STD) at 0.1 $\mathrm{mg} / \mathrm{mL}$ and injecting $30 \mu \mathrm{L}$, the capsaicin peak was confirmed at an RT of $27.5 \mathrm{~min}$ (Fig. 1A). With CP, the peak expected by capsaicin was not found (Fig. 1C), but in CP 100 a peak at an RT of 27 min was detected (Fig. 1B). Therefore, quantitative analysis was performed to determine the content of capsaicin, the effective substance, based on CP 100. From the results of calculating the correlation coefficient $\left(\mathrm{R}^{2}\right)$ of the calibration curve and linearity by analyzing the capsaicin standard at four concentrations $(200,400,600,1,000 \mu \mathrm{g} / \mathrm{mL})$, it was possible to secure linearity with a correlation coefficient of 0.999 or more 

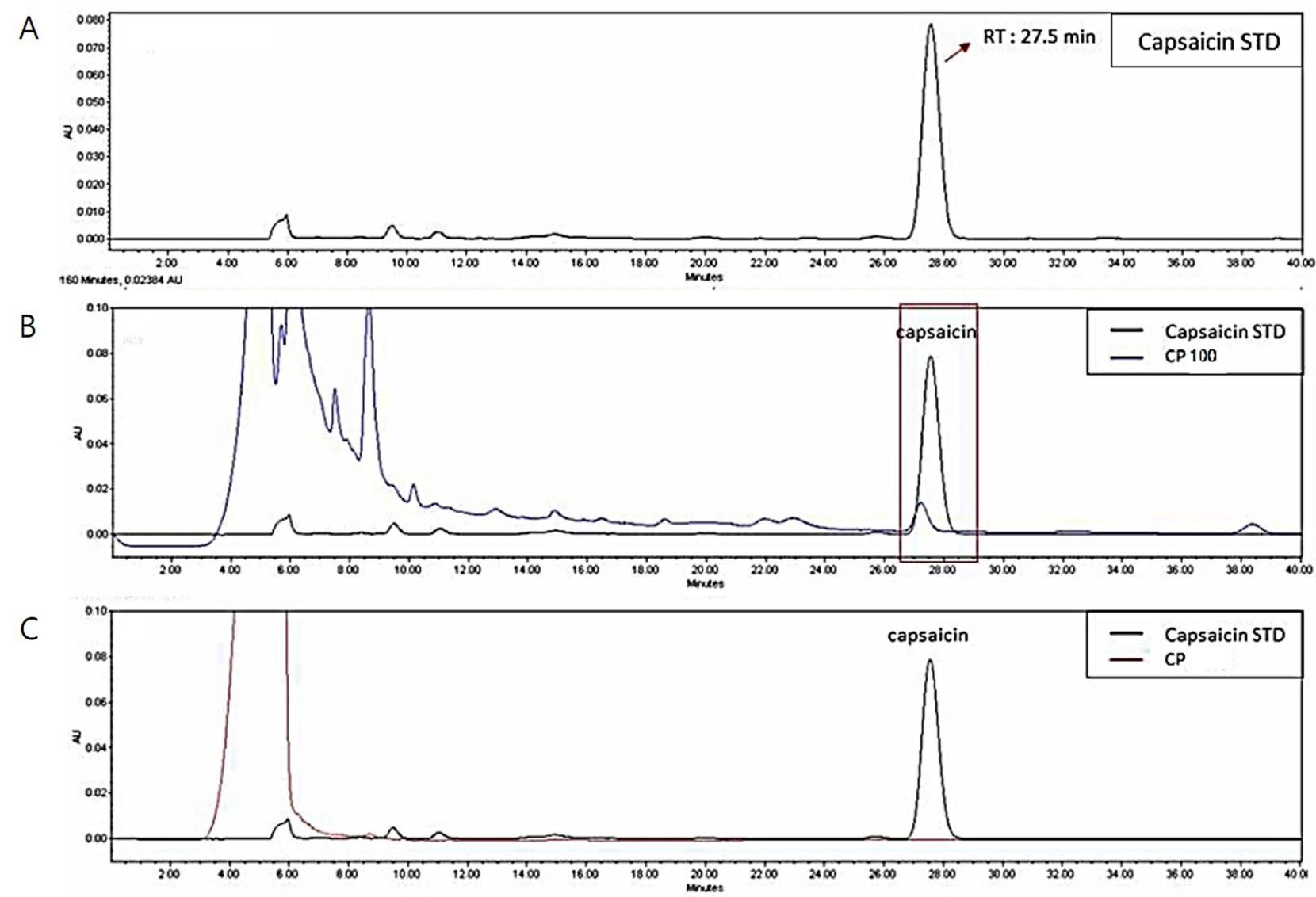

Figure 1. HPLC pattern analysis of CP (C), CP100, 100 times of CP (B), and capsaicin standard (STD) (A).

(Fig. 2E). By calculating the content of capsaicin in CP100 $(141.363 \mu \mathrm{g} / \mathrm{mL}$, Fig. $2 \mathrm{~F})$, the capsaicin content when preparing the CP was calculated based on CP100. From these results, it can be expected that the CP contained $1.414 \mu \mathrm{g} / \mathrm{mL}$ of capsaicin.

\section{Result of the dose setting test}

In the dose setting test, no abnormalities of general symptoms and death of animals by the test substance, CP, were observed at all doses in both sexes. In addition, during the observation period, no statistically significant changes in body weight were found in all doses of the CP group compared with the negative control group. Therefore, the maximum dose of this test was set to $0.2 \mathrm{~mL} /$ animal. Then, a geometric ratio of 2 was applied and CP groups with doses of 0.1 and $0.05 \mathrm{~mL} / \mathrm{ani}-$ mal were set. In addition, a negative control group and a positive control group were set.

\section{Micronucleus test in mice}

1) Effects of CP on the general health and body weight of the animals

During the observation period, there were no abnormal changes in the general appearance in the CP-treated group, at all doses (0.05, 0.1, $0.2 \mathrm{~mL} /$ animal) (Table 2). During the observation period, no statistically significant change in body weight was observed for any doses of CP in comparison with the negative-control group (Table 3).

\section{2) Effects of CP on the incidence of MNPCE in PCE and the ratio of PCE to total erythrocytes}

There was no significant difference between the CP group and the negative-control group in terms of the incidence of MNPCE in PCE. In addition, the ratio of PCE to total erythrocytes in the test substance groups was not significantly different from that in the negative-control group. The incidence of MNPCE in PCE increased statistically significantly $(\mathrm{p}<0.01)$ in the positive-control group compared with the negative-control 


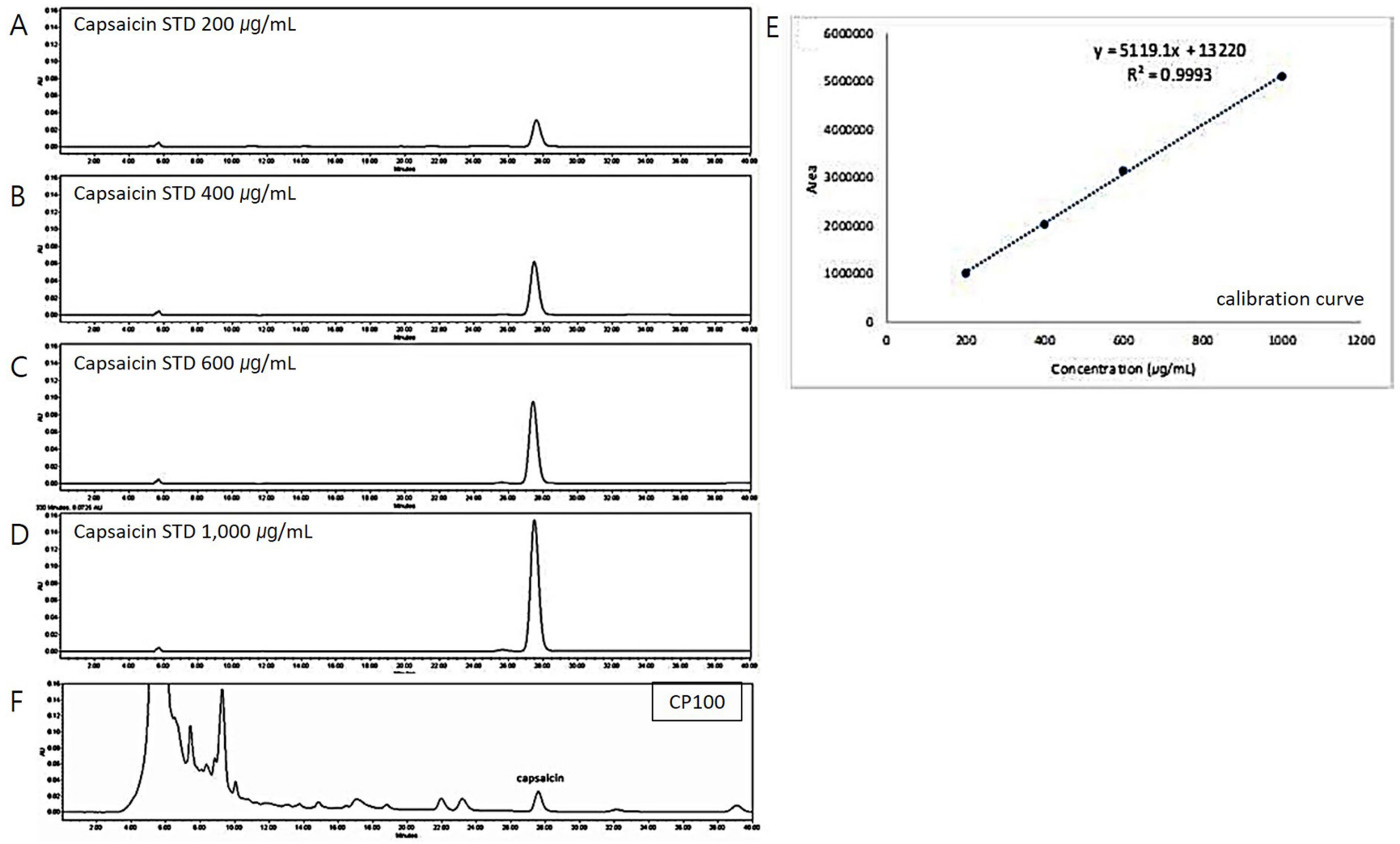

Figure 2. Quantitative analysis of capsaicin component of CP. The calibration curve (E) was calculated by analyzing the capsaicin standard (STD) at four concentrations, $200 \mu \mathrm{g} / \mathrm{mL}$ (A), $400 \mu \mathrm{g} / \mathrm{mL}$ (B), $600 \mu \mathrm{g} / \mathrm{mL}$ (C), and 1,000 $\mu \mathrm{g} / \mathrm{mL}$ (D). The capsaicin content of CP was calculated based on the calculation of the capsaicin content of CP100, 100 times of CP (F).

Table 2. Clinical signs of main study in male ICR mice

\begin{tabular}{|c|c|c|c|c|c|c|c|c|c|}
\hline \multirow{3}{*}{ Group } & \multirow{3}{*}{$\begin{array}{c}\text { Dose } \\
\text { (mL/animal) }\end{array}$} & \multirow{3}{*}{$\begin{array}{l}\text { Number } \\
\text { of animals }\end{array}$} & \multirow{3}{*}{ Route } & \multicolumn{6}{|c|}{ Clinical signs } \\
\hline & & & & \multicolumn{2}{|c|}{ 1st dosing } & \multicolumn{3}{|c|}{ 2nd dosing } & \multirow{2}{*}{$\begin{array}{l}1 \text { day after } \\
2 \text { nd dosing }\end{array}$} \\
\hline & & & & $\begin{array}{l}\text { Immediately } \\
\text { after dosing }\end{array}$ & $\begin{array}{c}2 \text { hours } \\
\text { after dosing }\end{array}$ & $\begin{array}{l}\text { Before } \\
\text { dosing }\end{array}$ & $\begin{array}{l}\text { Immediately } \\
\text { after dosing }\end{array}$ & $\begin{array}{c}2 \text { hours } \\
\text { after dosing }\end{array}$ & \\
\hline $\begin{array}{l}\text { Negative control } \\
\text { (normal saline) }\end{array}$ & 0 & 5 & I.M. & - & - & - & - & - & - \\
\hline \multirow[t]{3}{*}{$\mathrm{CP}$} & 0.05 & 5 & I.M. & - & - & - & - & - & - \\
\hline & 0.1 & 5 & I.M. & - & - & - & - & - & - \\
\hline & 0.2 & 5 & I.M. & - & - & - & - & - & - \\
\hline $\begin{array}{l}\text { Positive control } \\
\text { (MMC) }\end{array}$ & $2 \mathrm{mg} / \mathrm{kg}$ & 5 & I.P. & & & - & - & - & - \\
\hline
\end{tabular}

I.M., intramuscular; I.P., intraperitoneal; MMC, mitomycin C; -, no observable abnormality.

group. The ratio of PCE to total erythrocytes in the positivecontrol group was not significantly different from that in the negative-control group (Table 4).

The frequency of occurrence of MNPCE in the negative control group was within the range of historical control data and $95 \%$ of historical control data. In addition, the frequency of
MNPCE in the positive control group was within the management range of the historical control data (Table 5) and increased statistically significantly $(\mathrm{p}<0.01)$ compared with the negative control group; therefore, it was judged that this test was conducted under appropriate test conditions. 
Table 3. Changes in body weight of mice in the in vivo micronucleus test

\begin{tabular}{lcccc}
\hline \multicolumn{1}{c}{ Group } & Dose & Route & \multicolumn{2}{c}{ Body weight (g) } \\
\cline { 4 - 5 }$(\mathrm{mL} /$ animal) & & Before 1st dosing & 1 day after 2nd dosing \\
\hline Negative control (normal saline) & 0 & I.M. & $35.1 \pm 1.37$ & $34.3 \pm 1.63$ \\
CP & 0.05 & I.M. & $35.1 \pm 1.16$ & $34.3 \pm 1.12$ \\
& 0.1 & I.M. & $35.0 \pm 1.75$ & $35.1 \pm 1.55$ \\
Positive control (MMC) & 0.2 & I.M. & $34.9 \pm 0.84$ & $34.5 \pm 1.28$ \\
\hline
\end{tabular}

I.M., intramuscular; I.P., intraperitoneal; MMC, mitomycin C. Data are presented as mean \pm S.D. (standard deviation).

Table 4. Ratio of polychromatic erythrocytes (PCE) to total erythrocytes in male mice in in vivo micronucleus test

\begin{tabular}{|c|c|c|c|c|c|c|c|}
\hline Group & $\begin{array}{c}\text { Dose } \\
\text { (mL/animal) }\end{array}$ & $\begin{array}{l}\text { Number } \\
\text { of animals }\end{array}$ & Route & $\begin{array}{l}\text { Hours after } \\
\text { dosing (h) }\end{array}$ & & PCE (PCE + NCE) & MNPCE/PCE \\
\hline \multirow{2}{*}{$\begin{array}{l}\text { Negative control } \\
\text { (normal saline) }\end{array}$} & \multirow[t]{2}{*}{0} & \multirow[t]{2}{*}{5} & \multirow[t]{2}{*}{ I.M. } & \multirow[t]{2}{*}{24} & Total & $781 / 2,500$ & $5 / 10,000$ \\
\hline & & & & & $\%$ (Mean \pm S.D.) & $31.2 \pm 3.05$ & $0.025 \pm 0.025$ \\
\hline \multirow[t]{6}{*}{$\mathrm{CP}$} & \multirow[t]{2}{*}{0.05} & \multirow[t]{2}{*}{5} & \multirow[t]{2}{*}{ I.M. } & \multirow[t]{2}{*}{24} & Total & $737 / 2,500$ & $8 / 10,000$ \\
\hline & & & & & $\%$ (Mean \pm S.D.) & $29.5 \pm 1.89$ & $0.040 \pm 0.029$ \\
\hline & \multirow[t]{2}{*}{0.1} & \multirow[t]{2}{*}{5} & \multirow[t]{2}{*}{ I.M. } & \multirow[t]{2}{*}{24} & Total & $803 / 2,500$ & $9 / 10,000$ \\
\hline & & & & & $\%($ Mean \pm S.D. $)$ & $32.1 \pm 2.64$ & $0.045 \pm 0.021$ \\
\hline & \multirow[t]{2}{*}{0.2} & \multirow[t]{2}{*}{5} & \multirow[t]{2}{*}{ I.M. } & \multirow[t]{2}{*}{24} & Total & $865 / 2,500$ & $11 / 10,000$ \\
\hline & & & & & $\%($ Mean \pm S.D. $)$ & $30.9 \pm 2.10$ & $0.040 \pm 0.029$ \\
\hline \multirow{2}{*}{$\begin{array}{l}\text { Positive control } \\
\text { (MMC) }\end{array}$} & \multirow[t]{2}{*}{$2 \mathrm{mg} / \mathrm{kg}$} & \multirow[t]{2}{*}{5} & \multirow[t]{2}{*}{ I.P. } & \multirow[t]{2}{*}{24} & Total & $794 / 2,500$ & $1,200 * / 20,000$ \\
\hline & & & & & $\%($ Mean \pm S.D. $)$ & $31.8 \pm 3.08$ & $6.000 \pm 0.907$ \\
\hline
\end{tabular}

I.M., intramuscular; I.P., intraperitoneal; MNPCE, micro nucleated polychromatic erythrocytes; PCE, polychromatic erythrocytes; NCE, normochromatic erythrocytes; MMC, mitomycin C; S.D., standard deviation. Significant difference from negative control by Mann-Whitney test: ${ }^{*} p<0.01$.

Table 5. Historical control data

\begin{tabular}{|c|c|c|c|c|c|c|c|}
\hline \multicolumn{8}{|c|}{ Historical control values of micronucleated polychromatic erythrocyte (MNPCE) } \\
\hline \multirow{2}{*}{ Group } & \multirow{2}{*}{$\begin{array}{l}\text { Hours after } \\
\text { dosing (h) }\end{array}$} & \multirow{2}{*}{$\begin{array}{c}\text { Dose } \\
(\mathrm{mg} / \mathrm{kg})\end{array}$} & \multirow{2}{*}{$\mathrm{N}$} & \multirow{2}{*}{$\begin{array}{c}\text { MNPCE/PCE (\%) } \\
\text { (Mean } \pm \text { S.D.) }\end{array}$} & \multicolumn{2}{|c|}{ Range [MNPCE/PCE] (\%) } & \multirow{2}{*}{$\begin{array}{l}\text { 95\% control limit } \\
\text { [MNPCE/PCE] }\end{array}$} \\
\hline & & & & & MIN & MAX & \\
\hline Positive control & 24 & 2 & 32 & $6.119 \pm 1.275$ & 4.988 & 7.250 & \\
\hline \multicolumn{8}{|c|}{ Historical control values of ratio of polychromatic erythrocyte (PCE) to total erythrocytes } \\
\hline Group & $\begin{array}{l}\text { Hours after } \\
\text { dosing (h) }\end{array}$ & $\begin{array}{c}\text { Dose } \\
(\mathrm{mg} / \mathrm{kg})\end{array}$ & $\mathbf{N}$ & (Mean \pm S.D.) & MIN & & MAX \\
\hline Negative control & 24 & 0 & 32 & $30.66 \pm 3.006$ & 25.96 & & 35.36 \\
\hline Positive control & 24 & 2 & 32 & $29.39 \pm 3.864$ & 24.72 & & 34.07 \\
\hline
\end{tabular}

Negative control: Water for injection, Normal saline injection, Corn oil, $0.5 \%$ methyl cellulose 1500 centipoise solution, $0.5 \%$ carboxymethylcellulose sodium salt solution, etc.

Positive control: Mitomycin C (2 mg/kg, I.P., single dosing).

$\mathrm{N}$ : The total number of micronucleus test.

The above historical control values were obtained from the data pooled from Dec. 6, 2013 to Mar. 17, 2017.

The range was calculated by the control limit of

The range was calculated by the control limit of $\underline{X}-\underline{R}$ value.

a) Poisson-based $95 \%$ control limits of the historical negative control data. 


\section{DISCUSSION}

The safety and efficacy of herbal medicine used in TCM and KM have been proven over the long term through clinical experience, but some studies have reported side effects and safety concerns for herbal medicines [21, 22]. Non-clinical toxicity assessment of medicinal plants and herbal medicines serves as the basis for proving the safety of these drugs, and is also a necessary study for approval of clinical trials [17-19, 23]. Therefore, it is very important to test herbal medicines scientifically for toxicity. In KM, a variety of pharmacopuncture medicines are currently used in traditional clinics and a large number of pharmacopuncture medicines have been developed, based on various literature reports and clinical experience. In the case of pharmacopuncture, the treatment route is via acupuncture point administration rather than oral administration; therefore, there is a need to perform a toxicity evaluation study to prepare a scientific and public trust foundation and assess the safety of this fairly new pharmacopuncture medicine.

This study was performed to investigate the potential of $\mathrm{CP}$ to induce micronuclei in mouse bone marrow cells when $\mathrm{CP}$ was administered twice at 24-hour intervals, intramuscularly, in ICR mice. The micronucleus test allows detection of mutagenic substances, as it evaluates changes in the equal distribution of chromosomes during cell division [17, 19, 23, 24]. In this study, the micronucleus test in male ICR mice did not show significant increases in the frequency of micronuclei at any dose of $\mathrm{CP}$ compared with the negative-control group. Based on the results of this study, CP did not appear to induce micronuclei formation in mouse bone marrow cells.

In this study, a micronucleus test was performed using 8 -week-old ICR male mice bone marrow cells. In order to set the micronucleus test dose, $\mathrm{CP}$ at doses of $0.2,0.1$, and 0.05 $\mathrm{mL} /$ animal was administered into the muscles of the mice twice at 24-hour intervals, and no abnormalities of general symptoms, statistically significant changes in body weight, and animal deaths caused by the test substance, $\mathrm{CP}$, were observed at all doses. Therefore, the micronucleus test dose group of $\mathrm{CP}$ was set to $0.2,0.1$, and $0.05 \mathrm{~mL} / \mathrm{animal}$ and administered to the muscles of the mice twice at 24-hour intervals, and the frequency of MNPCE was measured by collecting bone marrow 24 hours after the second administration of the test substance.

The results showed that there was no significant difference in the frequency of MNPCE in all test groups compared with the negative control group administered with normal saline, and no significant difference was observed in the ratio of PCE to total red blood cells compared with the negative control group. However, in the positive control group administered with mitomycin $\mathrm{C}$, the frequency of occurrence of MNPCE among PCEs was significantly increased compared with that of the negative control group, and the ratio of PCE to total erythrocytes decreased significantly compared with the negative control group.

$\mathrm{CP}$ was developed to treat neuropathic pain and musculoskeletal diseases especially by utilizing the capsaicin component contained in red pepper. Through quantitative analysis with a calibration curve using a capsaicin standard of 200, 400, 600, and $1,000 \mu \mathrm{g} / \mathrm{mL}$, it was confirmed that the capsaicin content of CP100 was $141.363 \mu \mathrm{g} / \mathrm{mL}$. CP used in actual KM clinical practice is diluted to $1 / 100$, which made it difficult to directly identify the capsaicin components, but based on the result for the capsaicin content of CP 100 it can be expected that the capsaicin contained in $\mathrm{CP}$ is $1.414 \mu \mathrm{g} / \mathrm{mL}$.

Through the above results, it was determined that the micronucleus induction of the test substance, $\mathrm{CP}$, against mouse bone marrow cells was negative under this test condition. $\mathrm{CP}$ is usually used at $1 \mathrm{~mL}$ for a $60 \mathrm{~kg}$ adult (about $0.94 \mathrm{mg} / \mathrm{kg}$ ) at one time, and the $0.2 \mathrm{~mL} /$ animal dose used in this study is $380 \mathrm{mg} /$ $\mathrm{kg}$, which is 404 times more than the actual clinical use of CP. This result can be regarded as evidence for securing the safety of the use of $\mathrm{CP}$ in clinical settings.

Further studies on the long-term effects and effects of multiple doses of $\mathrm{CP}$ are needed before pharmacopuncture with $\mathrm{CP}$ can be established as an effective treatment method for patients with pain. If additional toxicological studies, such as in vitro chromosomal abnormality testing and in vitro mouse lymphoma TK analysis, as well as additional studies related to confirming the safety of $\mathrm{CP}$ in the human body can be conducted, the safety of using $\mathrm{CP}$ in clinical practice can be firmly established.

\section{CONCLUSION}

In conclusion, our toxicity study demonstrated that $\mathrm{CP}$ did not show any indication of inducing micronuclei formation in mouse bone marrow cells. Thus, CP may be safe for use in pharmacopuncture treatment of patients in traditional medicine clinics. Although safety was confirmed in this animal experiment, further studies are needed to confirm its safety in the human body. 


\section{ACKNOWLEDGMENT}

This work was supported by from the National Research Foundation of Korea (NRF) grant funded by the Korean government (MSIT) (No. NRF- 2017R1C1B5076224).

\section{CONFLIGT OF INTEREST}

The authors declare no conflicts of interest.

\section{AUTHORS' CONTRIBUTIONS}

C Jung designed all of the experiments together. JH Hwang performed the statistical analysis, interpreted the experimental results, and wrote the manuscript. C Jung and J Gu revised the manuscript. All authors read and approved the final manuscript.

\section{AVAILABILITY OF DATA AND MATERIAL}

The data set generated and analyzed during the study are available from the corresponding author on reasonable request. All materials used in this study are properly included in Methods section.

\section{ORCID}

Ji Hye Hwang, https://orcid.org/0000-0002-6304-1972

Jaseung Ku, https://orcid.org/0000-0003-4365-5587

Chul Jung, https://orcid.org/0000-0002-2522-5279

\section{REFERENCES}

1. Singletary K. Red pepper: overview of potential health benefits. Nutr Today. 2011;46(1):33-47.

2. Pawar SS, Bharude NV, Sonone SS, Deshmukh RS, Raut AK, Umarkar AR. Chillies as food, spice and medicine: a perspective. Int J Pharm Biol Sci. 2011;1(3):311-8.

3. Silva C, Rio ME, Cruz F. Desensitization of bladder sensory fibers by intravesical resiniferatoxin, a capsaicin analog: longterm results for the treatment of detrusor hyperreflexia. Eur Urol. 2000;38(4):444-52.

4. McCarty MF, DiNicolantonio JJ, O’Keefe JH. Capsaicin may have important potential for promoting vascular and metabolic health. Open Heart. 2015;2(1):e000262.

5. Ito K, Nakazato T, Yamato K, Miyakawa Y, Yamada T, Hozumi N, et al. Induction of apoptosis in leukemic cells by homovanillic acid derivative, capsaicin, through oxidative stress: implication of phosphorylation of p53 at Ser-15 residue by reactive oxygen species. Cancer Res. 2004;64(3):1071-8.

6. Hail N Jr, Lotan R. Examining the role of mitochondrial respiration in vanilloid-induced apoptosis. J Natl Cancer Inst. 2002; 94(17):1281-92.

7. Ständer S, Luger T, Metze D. Treatment of prurigo nodularis with topical capsaicin. J Am Acad Dermatol. 2001;44(3):471-8.

8. Jung C, Jung JH, Lee MS. A clinical study of immune pharmacopuncturology. Yeongi: Kyungrak Medical Publishing Co.; 2011. p. 127-33.

9. Korean Acupuncture and Moxibustion Society. Acupuncture medicine. Seoul: Hanmi Medical Publishing Co.; 2020. 932 p.

10. Kim HJ, Gwan R, Han JW, Jung C. Anti-oxidant anti-inflammatory effects of V Yakchim. J Korea Immuno-Yakchim Soc. 2013; 2(1):1-8.

11. Jung C. In vivo micronucleus test of V-YAKCHIM in ICR mice. J Korea Immuno-Yakchim Soc. 2013;2(2):5-10.

12. Cho S, Jung C, Kim K, Ko S, Jung H, Park J. A case study of acute appendicitis improved by pharmacopuncture treatment. J Intern Korean Med. 2019;40(2):208-19.

13. Chung YJ, Lee HJ, Lee YK, Lee JH, Gong HM, Jun SA, et al. Case report of hypoesthesia of lower limb with additional CP pharmacopuncture. J Physiol Pathol Korean Med. 2019;33(2):158-62.

14. Jeong JH, Hwang JH. Korean medicine treatment including capsaicin-containing (CP) pharmacopuncture for acute low back and hip pain: a case report of 3 patients. Korean J Acupunct. 2020;37(3):191-7.

15. Hwang JH, Ku J, Jung C. Evaluation of the single-dose toxicity of capsaicin pharmacopuncture in rats. J Acupunct Res. 2020; 37(3):167-72.

16. Hwang JH, Ku J, Jung C. Bacterial reverse mutation test of $\mathrm{CP}$ pharmacopunture. J Korean Med. 2020;41(3):55-68.

17. Korea Food and Drug Administration (KFDA). Good Laboratory Practice (GLP). [Internet]. Cheongju: KFDA; c2017 [cited 2017 May 1]. Available from: http://www.law.go.kr/admRulInfoP. do?admRulSeq=2100000086689.

18. Korea Food and Drug Administration (KFDA). Partial Amendment Official Announcement about Toxicity Test for Drug [Internet]. Cheongju: KFDA; 2015 Nov 11 [updated 2015 Nov 11; cited 2015 Nov 11]. Available from: https://www.law.go.kr/ LSW/admRulLsInfoP.do?chrClsCd=010202\&admRulSeq= 2100000032147.

19. Organisation for Economic Co-operation and Development (OECD). ENV/MC/CHEM(98)17: OECD series on principles of good laboratory practice and compliance monitoring number 1 . Paris: OECD; 1998. 41 p. 
20. Diehl KH, Hull R, Morton D, Pfister R, Rabemampianina Y, Smith $\mathrm{D}$, et al. A good practice guide to the administration of substances and removal of blood, including routes and volumes. J Appl Toxicol. 2001;21(1):15-23.

21. Teschke R, Wolff A, Frenzel C, Schulze J. Review article: herbal hepatotoxicity--an update on traditional Chinese medicine preparations. Aliment Pharmacol Ther. 2014;40(1):32-50.

22. Kim EJ, Chen Y, Huang JQ, Li KM, Razmovski-Naumovski V, Poon J, et al. Evidence-based toxicity evaluation and scheduling of Chinese herbal medicines. J Ethnopharmacol. 2013;146(1):4061.

23. Lee MY, Seo CS, Kim JY, Shin HK. Genotoxicity evaluation of Guibi-Tang extract using an in vitro bacterial reverse mutation assay, chromosome aberration assay, and in vivo micronucleus test. BMC Complement Altern Med. 2014;14:215.

24. Kirsch-Volders M, Sofuni T, Aardema M, Albertini S, Eastmond $\mathrm{D}$, Fenech $\mathrm{M}$, et al. Report from the in vitro micronucleus assay working group. Mutat Res. 2003;540(2):153-63. 